\title{
Legislative Based Analysis on the Implementation of Rural Land Laws in Oromia Region: Bale Zone in Focus
}

\author{
Solomon Girma Tadesse, Temesgen Solomon Wabelo \\ School of Law, Madda Walabu University, Bale Robe, Ethiopia \\ Email: solomon.girma@mwu.edu.et or temesgensolomon1@gmail.com
}

How to cite this paper: Tadesse, S. G., \& Wabelo, T. S. (2019). Legislative Based Analysis on the Implementation of Rural Land Laws in Oromia Region: Bale Zone in Focus. Beijing Law Review, 10, 806-828. https://doi.org/10.4236/blr.2019.104044

Received: May 13, 2019

Accepted: August 17, 2019

Published: August 20, 2019

Copyright $\odot 2019$ by author(s) and Scientific Research Publishing Inc. This work is licensed under the Creative Commons Attribution International License (CC BY 4.0).

http://creativecommons.org/licenses/by/4.0/

Open Access

\begin{abstract}
The article has explored the legislative analysis on the implementation of rural land laws of Oromia region state with special focus on Bale Zone, Ethiopia. Assessing the implementation of Oromia rural land proclamation and identifying possible challenges have been the main objective of this research. In order to achieve this objective, qualitative research methods were employed. Land administration head and experts, Judges, Kebele administrators, Kebele land administration committees and legal attorneys were used as the key informants. Observation, interview and focus group discussions were also utilized for the success of the study. Relevant rural land proclamations and literatures of most highly qualified scholars on the area were deeply examined. Finally, the research article has found that rural land law of region is not fully implementing in the study area. Absence of specific rural land implementation guidelines, weak and understaffed institutions, lack of effective dispute resolutions system, inadequate financial sources, land grabbing, existence of double holding certificates, $\mathrm{d}$ land sale and absence of legal knowledge are identified as the main challenges for the implementation of rural land laws in Oromia Region.
\end{abstract}

\section{Keywords}

Rural Land, Rural Land Proclamation, Oromia Land Administration

\section{Introduction}

Land is crucial and a single most important source of wealth and social prestige in many societies of the world. Studies reveal that approximately one-half of the world's total economic wealth comes from land (Ling \& Archer, 2005). Moreover, the issue of land has not simply remained to be an economic affair but also 
it is very much connected with the people's culture and identity. Scholars have indicated how the land issue is intermingled with the people's culture and identity. As to Shipton noted "land tenure and attempts to change or reform it cannot be understood without knowing who is buried on that land, and what sorts of kin groups or other entities claim attachment to those meaning laden graves" (Shipton 2009). This quotation reflects that the issue of land is highly connected with the people's identity. To this end, well-functioning land laws and institutions have crucial impacts to improve the development of the sector.

Today the world faces many complex challenges like rapid urbanization, increased demand for natural resources, water and energy insecurity, increased natural disasters, and conflicts. Due to this reason, international institutions have formulated policies to shore up the national land law policies. For instance, United Nations Voluntary Guideline for the responsible governance of tenure of land has pointed out pillars for effective land policy i.e. tenure security over land for the holders, providing commensurate compensation at the time of expropriation, avoiding land grab in the name of investment and providing secure tenure rights for women, youth, pastoralists and communal land holders (Voluntary Guidelines on the Responsible Governance of Tenure of Land, Fisheries and Forests, 2012).

Regionally, the African frame work guideline on land policy and the declaration on Land issues are a joint product of the partnership between African Union (AU), Economic Commission for Africa (ECA) and the African Development Bank (AfDB), and have indicated basic elements for effective national land policy (Framework and guidelines on land policy in Africa, 2010, Declaration on Land Issues and Challenges in Africa, 2009, effective implementation of land laws) (Sen, 1981).

Ethiopia has also issued a rural land law entitled Federal rural land administration and use proclamation (FRLAUP) in 2005 (Proclamation No. 456/2005) by amending Proclamation No. 89/1997. This proclamation bestows the regional governments including Oromia, the power to enact their respective regional rural land administration and use laws and establish institutions to each regional state council so as to implement FRLAUP 2005 in the regions (Proc. No. 456/07, article 17(1)(2)). Based on this stipulation, Oromia regional state has enacted its own rural land administration and use law named as Oromia rural land administration and use proclamation No.130/2007.

Dissatisfaction on the amount of compensation and land grab related with foreign direct investment has become the main concern and challenge in Ethiopia (USAID, 2012). The land laws are not answered the land question of women because the influence of customary laws waives the implementation of formal land rights granted by the law. The finding of this study has also indicated that the awareness of the public on the area is low (Ibid). Other researches carried out on the implementation rural land laws in Ethiopia have also revealed that the implementation of rural land laws was weak and didn't bring required changes at community level (SIDA, 2003; Holden and Tefera, 2008). 
Moreover, scholars strongly argues that effective land laws and implementing institutions are an important determinant factor for responding land tenure related problems and the overall quality of land governance. It is found that, in both formal and customary land tenure arrangements, poor are particularly vulnerable to the effects of weak governance as they lack ability to protect the rights to land and other natural resources (Palmer, Fricska, \& Wehrmann, 2009). Researchers on the subject area confirm that, even though Ethiopia has recently adopted innovative and pro-poor land laws, still these laws lack an implementation (Deninger, 2008). Similar problems are also identified by the World Bank and USAID studies in Ethiopia.

Oromia regional state is one of the region that constitutes 40 million of the estimated population overall 100 million population of Ethiopia (Central Statistics Agency, 2017). The regional state is located within $3^{\circ} 24^{\prime} 20^{\prime \prime}-10^{\circ} 23^{\prime} 26^{\prime \prime} \mathrm{N}$ latitudes and $34^{\circ} 07^{\prime} 37^{\prime \prime}-42^{\circ} 58^{\prime} 51^{\prime \prime} \mathrm{E}$ longitudes, extending for about eight degrees $\left(8^{\circ}\right)$ west to east and for about seven degrees $\left(7^{\circ}\right)$ north to south or vice versa excluding Oromiya Zone of Amhara National Regional State (Central Statistics Agency, 2017).

Bale zone has a population of 1,402,492 with an area of 43,690.56 km square. Among this, 713,517 of the population are male \& 688,975 are female. As far as the distribution of the population by urban-rural distinction is concerned 166,755 of the total population is urban \& 1,235,736 is rural among which 44,610 are pastoralists. In bale zone there are about 13,203 disabled persons among them 7174 are male and 6029 are female. The average literacy rate of the population of the zone is $37.9 \% \& 45.1 \%$ for male $\& 30.5 \%$ for female. Out of 901,515 inhabitants of Bale zone aged 10 years and above, 597,203 of the population is economically active while 304,312 is economically in active. From this economical active population of the zone 582,419 are employed while 14,784 are unemployed. The unemployment rate is therefore $2.5 \%$ (CSA, 2015) Thus, this research article has investigated the practical challenges for the implementation of rural land laws of Oromia with a focus Bale zone.

\section{Methods}

This research article has explored employed non doctrinal legal research approach and empirical qualitative methods based on the nature of data collected. Data from primary sources has been focus on perception of respondents on the implementation of land laws, their awareness of land laws and their participation at the time of enforcement of land laws in the study area. As a result, questionnaire, interview, focus group discussion (FGD) have been taken. Secondary data were also collected from different documents and literatures.

To this end, the study used relevant literature materials like journals, books, research papers conducted on related areas, land policies and reports and internet websites. The study zone consists of eighteen woredas and two city administrations. From this study zone, the research team has purposively selected five woredas by considering their geographic size, size of the population and by con- 
sidering whether the inhabitants of the woreda are pastoralists and/or highland farmers. By applying this, Sinana, Ginir, Gololcha, Agerfa and Dolomena woredas were selected. Concerning the size of study population i.e. Court Officials, Judges, Advocates, Kebele administrators, Kebele land administration committees and woreda land administration experts were selected based on their work experience on the study areas. Based on this, five judges and one court president from each sample woreda were selected and the total of twenty five judges and five court officials (court presidents) were addressed.

With regards to rural land administration experts is concerned, five experts were selected based on their experience and the total of twenty five experts were addressed from each woreda. In addition to rural land administration experts, the research team has also interviewed all of rural land administration office heads of the woredas in the study zone and a total of eighteen office heads were addressed by the study. Due to their limited number of legal attorneys in the study zone, all available attorneys of each zone in the study areas were addressed and the research team has found a total of twenty attorneys. Finally, the research team purposively selected two kebeles from each category of sample woredas and two Kebele administrator and five land administration committee members from each the selected Kebeles were addressed and a total of fifty land administration committee members and twenty kebele administrators were addressed.

\section{Literature Review}

\subsection{History of Land in Ethiopia}

The history of land tenure, major socio-economic asset in Ethiopia, is closely tied to the foundation and formation of the nation itself (Daniel Behailu, 2015). The way land rights are defined influences how land resources are used and, hence, economic growth. The struggle over who controls the land is highly related question of controlling power in the history of Ethiopia. Three periods can be distinguished in relation to land tenure policy and changes: the pre-1975 land tenure system, the rule of the Derg until 1991, and the period since 1991 (Berhanu Adinew and Feyera Abdi, 2005).

The pre-1975 land tenure system which is sometimes called the Imperial regime was divers in nature. The nature of the land tenure arrangement comprises private, state, church land, kinship and other forms (Markakis and Ayele, 1976). The Derg, in its land reform in 1975 appropriated all land and abolished the diverse tenure arrangements in the imperial regime. Landlords lost their land rights and land was distributed to individual households, with household System size being the main criterion for land allocation (Action Aid Ethiopia, 2006). As household sizes change over time and new households appear, there was also a need to redistribute land at later stages to improve or maintain the egalitarian distribution and to provide land to new landless households (Holden Stein and Yohannes, 2002).

Frequent administrative land redistributions, constrained access, caused te- 
nure insecurity, fragmentation of land holdings, inefficient allocation of land, is discouraging rural-urban labor movement, and inappropriate land administration practices were among important features of the rural land policy from 1975-1991 (Daniel Behailu, 2015). Since 1991 Ethiopia has decentralized land policy responsibilities to the regional level and regional land proclamations were developed, following but not undermining the federal land proclamation. Based on this, a number of laws relevant to the rural land use and administration have been adopted in the Oromia Regional State since 2002.

\subsection{The Legal Framework of Oromia Land Law}

\subsubsection{Proclamation No. $56 / 2002$}

In 2002 Oromia regional state has issued a Proclamation No. 56/2002 entitled of “Oromia Rural land Use and Administration, Proc. No. 56/2002". The proclamation extends a lifelong use right of agricultural land and provides for expropriation of such land under the exigencies of a need to use the land for a more important public purpose (Art. 4(6) of Oromia Rural Land Use and Administration Proclamation, 2002; Proclamation No.56/2002). The main objectives of this proclamation is to bring about proper management of land and land resources in an efficient and sustainable manner without compromising the development endeavor of the future generations and to determine the scope of rights, security and obligations of land users in accordance with the land policy of the nation (Preamble of Oromia Rural Land Use and Administration Proclamation, 2002).

The guiding principles of this legislation are outlined under Article 4 of the proclamation. Firstly, land is the common property of the state and the people, and therefore, it cannot be subject to sale or other means of exchange. Second, the law expressly provides that women must have equal rights with men as far as rights to land and access to rural land is concerned. Article 5 of the Proclamation stipulates that any adult resident of the region who is aged 18 years or above and who wishes to base his livelihood primarily on agriculture is entitled to get rural land free of payment. In light of the objectives of strengthening tenure security set out in the preamble of the proclamation, Article 6 (1) reaffirms that rights to holdings are for lifelong time and accordingly peasants and pastoralists have the right to use land under their possession during their life time and bequeath the same to members of their family.

The use right of holding the cannot be terminated during the life of that very holder unless and otherwise the land in question is required by the state for "more important public uses" after payment of prompt and adequate compensation for all investments and improvements on the land (Ibid, Proc No.56/2002 Article 6 (4) and (5)). The expropriation of land for public uses should not only be determined by the state and the latter has to do it in consultation with the local community. This law also lays down a number of obligations that landholders should fulfill as a precondition of exercising holding rights and keeping the land under possession for lifelong use. These obligations include proper management of land, maintaining and preserving farmland boundaries, refraining 
from activities that exacerbate soil erosion, refraining from cultivating gullies, ravines and river boundaries and rehabilitating same, undertaking soil and water conservation measures, refraining from planting harmful vegetation and caring for "mother trees" standing on farm plots (Ibid, Proc No. 56/2002, Arts.17-19 and 22-23).

\subsubsection{Proclamation No. 70/2003}

Proclamation No.70/2003 was amended by proclamation No. 56/2002. Taking the cultural settings of the State of Oromia, the amendment comes up with the issuance of holding right certificates to wife or husband in polygamous marriages. These measures seem to enhance the land rights of women but they tend to be superfluous in practical terms for the joint or separate registration title registration with same holding would cause problems of implementation. This law has also introduced some sort of changes on the preceding law. Firstly, transfer of use rights by holders through inheritance was restricted because the proclamation only permits transfer of holding rights through succession to one's children by narrowly defining the terms family member to constitute natural or adopted children of the holder (Proclamation No. 70/2003, Art.2(1)). Secondly, the new amendment authorizes the government to take away the holdings of peasants or pastoralists and grant leasehold for investors if the land in question is found to be important for public purpose. However the proclamation was amended by Proclamation No. 103/2005 and Proclamation No.130/2007 respectively.

\subsubsection{Proclamation No. $130 / 2007$}

To tackle problems encountered in preceding proclamations and to handle disputes relation with land tenure, the State of Oromia has enacted a new rural land use and administration law in 2007 (Proclamation No. 130/2007, preamble). The Proclamation No. 130/2007 is working land proclamation of the region and it is harmonized with the 2005 federal rural land proclamation. It reaffirms most of the principles and procedures of the predecessors. Some of the new inclusions in the new law are: the right of investors to mortgage the property acquired on land (through the investment process) and issuance of certificate of holding which could be prepared in the name of the rightful holder, be it joint ownership or otherwise.

\subsection{Rights and Obligations of Rural Landholders in Oromia}

\subsubsection{Access to Rural Land}

The right to access to rural land in free of charge is provided under federal (Federal Democratic Republic of Ethiopia Constitution, Proclamation No. 1/1995) and regional constitution like the revised Constitution of Oromia Regional State. In a similar vein, Proclamation No.130/2007, the latest rural land use and administration law of Oromia Regional State, attaches significant importance to secured land users rights as one of its primary goals that ensure a better right for rural land users including the right to access to rural land (Preamble of Procla- 
mation No. 130/2007). Article 5(5) of the Proclamation clearly indicated that "Any peasant, pastoralist or semi pastoralist having the right to use rural land may get rural land from his family by donation, inheritance or from government." Inheritance and donation are the principal possibilities for acquisition of rural land (Ibid, art. 6 (6)).

Transferring land use rights through inheritance or donation of land is restricted as it is only to family members whose livelihood depends on the income earned from the land in question or with no other means of income, or landless children of the holder that are entitled to acquire rural land for use through donation (Ibid, art. 9(5)). Children of the landholder having other means of income for their livelihood cannot acquire land use rights via donation. Governmental institutions, nongovernmental organizations, private investors and other social institutions are also entitled to get access to rural land (ibid, article 5(3)). The prevailing customary system also limits inheritance rights of women (Seifu, 2010).

The Proclamation made significant improvement in terms of protecting women's right to land by providing for equal rights for men and women to access rural land, recognizing equal rights to obtain land titles and joint titling for spouses, presuming joint holding of family land and the right to share their landholdings equally upon divorce, outlawing land rental agreements without consent of both spouses and permitting women to use hired labor on their farm plots (Article 15(8); article 6(13); article 10(6); article 6(14) of proc No.130/2007). However, prohibition of gender discrimination with regard to land has not produced significant change in terms of ensuring women's right to land in practice because of inapplicability of these relevant provisions due to obstacles such as the prevalence of entrenched prejudices and biased attitudes towards women in most part of the Region (Gudeta, p. 129). Therefore, it is said to be that women are practically discriminated in many parts of remote rural areas where customary norms are widely applied (ibid, Gudeta).

The proclamation also provides for the compulsory registration system of all categories of rural land holdings. Article 15(1) of this proclamation state that all private, communal and state holdings shall be measured and information regarding their size, land use and fertility, shall be collected and registered in the data centers. However, it is argued that the process of rural landholding certification has been causing conflicting claims and courts are said to be overloaded with a number of land disputes since 2004 when the land measurement and registration process began in the regional state (Gudeta, ibid). The certification process is also criticized for being cost ineffective and tainted with administrative inefficiency (Gudeta, ibid). No clear procedures exist for updating records, and neither registry books nor landholding certificates are structured in a way that would facilitate recording of changes in rights over time. There are no clear rules on when and how registers must be updated (for example, inheritance or short-term transfer) or what sanctions may be incurred if that is not done. This lack of requirements suggests that no information is available on recorded (or 
actual) transactions. These are not the only provisions of the proclamation but that what boldly dictate the rights of rural land holders.

\subsubsection{Land Use Rights}

The major rights of landholders are specified under Art. 6(1) of the Proclamation, among others, include: the right to use one's holding without any time limit, the right to lease out, the right to transfer use right over one's parcel of land to one's family members through inheritance or donation, the right to acquire property produced thereon and the right to sell, exchange and transfer such property and the right to claim compensation up on the expropriation of the holding rights for public purposes. Nevertheless, the right to dispose property produced on one's holding does not include the sale of land. As the land is exclusively owned by the state and peoples of Ethiopia, transfer of land by sale or any other means of exchange is prohibited. By the same token, the Proclamation, in principle, prohibits sell of fixed assets such as coffee, mango, avocado, papaya, orange etc (Art. 6(2) of Proc No. 130/2007).

1) However, the Proclamation provides that a fixed asset produced on one's holding may be sold exceptionally in the situation where:

2) The fixed asset to be sold should not exceed more than half of the total holding of the holder, and

3) The sale agreement of the product should not extend over a period of three years.

Such agreements must be registered and approved by the bureau in the same way as it is mandated to approve agreements for share cropping or hiring labor by vulnerable groups on their land holdings, overseeing and approving rental agreements and approving and registering special agreements rights holders make with investors to develop their holdings (Ibid, Art. 6(3); Ibid, Art. 6(15); Ibid, Art. 10(8)).

It is worth noting that use rights are guaranteed during the lifetime of the holder and it cannot be terminated unless the land is required for more important public purposes (ibid, art. 6(10)). The state is required to pay compensation in advance to the peasants whose landholdings were expropriated and such compensation comprises the value of the property on that land and calculation of the benefits obtained there from as well as replacement of similar plot of land (ibid, art. 6(11)). The Proclamation also provides that in case where replacement of land is not possible, the holder displaced from his parcel of land will be entitled to payment of compensation for rehabilitation (ibid, art. 6(12)). Thus, it can be concluded that Proclamation No. 130/2007 has tried to effectively address the issue of expropriation and compensation in relation to rural land holdings in the region.

Pursuant to this law, any holder has the right to rent out up to half of his/her total holding for three years if modern farming technology is utilized (ibid, art. 10(1)(2)). Nevertheless, agreements to rent rural holdings won't be valid unless approved and registered by Land Administration Bureau. Furthermore, the law 
requires that all family members including women, those who have interests in the land, must give their consent before any agreement to rent out rural land holding is concluded and on that land tax must be paid in the name of the landholders (ibid, art. 10(7)). The Proclamation seems to introduce the idea of obliging lessees to pay land tax in the name of the land holders with a view to securing the rights of land holders who rent out their land in the absence of properly defined and registered land rights throughout the region. The practice in the region shows that many of the disputes over rural land are related land rent transactions (Gudeta, p. 137).

The Proclamation also provides that the government can only rent out to investors when the land has not held by peasants or pastoralists (Proc No. 130/2007, Art. 11(1)). The agreement to grant land to investors through lease must protect the benefits of peasant and pastoralists in such a way that seems to give priorities in terms of accessing to farmers and pastoralists than private investors (ibid, art. 11(2)). In this manner, the law has addressed tenure insecurity that may be felt by rural land holders because of assignment via lease of large plots of land held by small holders for commercial agriculture as well as development of industrial projects to private investors by the way of expropriation.

\subsubsection{Obligations of Rural Land Holders}

There are certain obligations imposed on the use right holder. Some of the obligations imposed are: obligation to proper management of rural land, obligation to proper management of farm land, obligation to proper management of grazing land and obligation to proper utilization of lands (ibid, art. 19-25)). Proclamation No. 130/2007 incorporates provisions of obligations here and there. For instance, the proclamation under Article 6(16) provides for the main obligations that must be fulfilled by all rural land users are exercising use rights over the land continuously. In the first place, any rural land user who fails to conserve his holdings may lose his/her holding rights. Secondly, any rural land user who leaves his holdings uncultivated or unused for two consecutive years would be deprived of his/her use rights. The Proclamation contains provisions that provide for proper management and conservation of the land by abstaining from activities that exacerbate soil erosion, forest clearing and plotting sloppy land and refraining from planting tree species that may cause damage to the land and eradicate weeds that cause harm to land (ibid).

\section{Discussion}

\subsection{Manner of Exercising Land Rights of the Proclamation}

As indicated above land is exclusively owned by the state and peoples of Ethiopia, transfer of land by sale or any other means of exchange is prohibited. It is worth noting that use rights are guaranteed during the lifetime of the holder and it cannot be terminated unless the land is required for more important public purposes (ibid, art. 6(10)). The state is required to pay compensation in advance 
to the peasants whose landholdings were expropriated and such compensation comprises the value of the property on that land and calculation of the benefits obtained there from as well as replacement of similar plot of land (ibid, art. 6(11)). The Proclamation also provides that in case where replacement of land is not possible, the holder displaced from his parcel of land will be entitled to payment of compensation for rehabilitation (ibid, art. 6(12)).

But the discussion from FGDs and key informant interviews has disclosed different facts. As land is exclusively owned by the state and peoples of Ethiopia, the proclamation prohibits transfer of land by sale or any other means of exchange. The study populations believe that, land is being sold like other personal asset or property. Melaku Gishe, one of land use expert in Sinana woreda believes that the law is not protecting the users from selling land in practice. Discussion with Boke Tefera, Sinana woreda land administration and environmental protection office head also confirms the same. Tefera believes that land holders are selling their land by dissatisfying the amount of compensation at the time of expropriation. Discussion with Agerfa woreda land administration and environmental protection office has also disclosed similar fact with regard to sale of land is concerned. Agerfa Woreda land administration and environmental protection office head also believes that land holders are indirectly selling their land. An interview with all of Bale Zone land administration and environmental protection office heads has also confirmed the similar fact. They believe that land sale is the main challenge in the study area. For this reason one can find two or more land holding certificates within the same pilot of land. Land administration committees and kebele administrators also accept that land holders are selling their land simply by entering a fake contract of donation. Taman Hajiahmed, land administration committee member in Agerfa kebele confirms that land holders are certainly selling their land like any other asset or property. Discussion with kebele administrators and land administration committee members in Sinana woreda has also disclosed similar fact. They confirm that land holders are selling their land because of their weak confidence in government compensation. Land holders believe that the compensation paid at the time of land expropriation is not commensurate or not equivalent to the amount of money that they got from the produce of their land.

Another right that Oromia rural land proclamation provided for the land holders is the right to rent out up to half of his/her total holding for three years if modern farming technology is utilized (Ibid, Art. 10(1) and (2)). Nevertheless, agreements to rent rural holdings won't be valid unless approved and registered by the Bureau. Furthermore, the law requires that all family members including women, those who have interests in the land, must give their consent before any agreement to rent out rural land holding is concluded and that land tax must be paid in the name of the landholders in any land rented to others (ibid, art. $10(7))$.

But the practice of the study area shows that land holders are not entering valid contract with the lessee. Even they enter a contract for more than three 
years and they won't register the contract of rent by the relevant organ. Discussion with land administration office heads and experts of the study area divulges that, land holders do not care for the validity of the contract but the problem arises if there is disagreement by the contracting parties. They also confirm that, Land holders are leasing the fixed assets of their land for a longer period than the one that is indicated within the proclamation.

\subsection{Adequacy of Compensation at the Time of Expropriation}

According to Article 40(8) of FDRE constitution 'without prejudice to the right to private property, the government may expropriate private property for public purposes subject to payment in advance of compensation commensurate to the value of the property.' In a similar token, Article 6(10) of proclamation No. 130/2007 provides conditions in which rural land use rights are terminated. This is only if that the land is required for more important public purpose. Sub article 11 of this provision has depicted remedy by mandating any individual or organ whose land holding is taken for public uses to have the right to get compensation for his properties and benefits gets proportional replacement for his holding. As per Sub article 12 of this provision if replacement of holding is not possible, compensation for rehabilitation shall be paid. When a government decides to take private property rights to advance public purposes, it must make sure that an adequate due process is followed to determine whether a purpose for which the private property is taken will actually benefit the public and must pay a just compensation in advance.

Most of our study populations are unhappy by the amount of compensation paid at the time of expropriation. Even some respondents believe that the public purpose requirement depicted on the constitution is no fulfilling at the time of expropriation. They also believe that the amount of compensation paid in lieu of expropriation of rural land is not rehabilitating the victims to their previous position. In general, the expropriation of rural land without just compensation in Oromia in general and in the study area specifically violates Article 40(4-5) of the FDRE Constitution and Article 40 (4-5) of the Oromia Regional State Constitution, which recognize the rights of farmers and pastoralists to obtain land free of charge and protect them from evictions from their lands. The FDRE Constitution (Art. 40(4-5)) explicitly recognizes the right of peasants and pastoralists not to be evicted from their lands. At the time of expropriation of rural land for public purpose, landholders must be paid a just, advance and prompt compensation to translate the constitutional protection against evictions into practice meaningfully.

\subsection{Protection of Women's Land Rights}

FDRE constitution under article 35(1) confirmed that, 'Women shall, in the enjoyment of rights and protections provided for by this Constitution, have equal right with men'. The Constitution further prescribes that 'Women have the right 
to acquire, administer, control, use and transfer property. In particular, they have equal rights with men with respect to use, transfer, administration and control of land. They shall also enjoy equal treatment in the inheritance of property (Article 35(7), FDRE Constitution). Further, the Constitution assures that peasants, pastoralists and semi-pastoralists of both sexes have the right to get land for cultivation and grazing free of charge and without any danger of eviction from their possession (Article 40 (4)(5), FDRE Constitution). So these constitutional provisions construe women's right to use and control land and property in equal footing with men.

The Oromia regional state constitution has also adopted verbatim copies of article 34 and 35 of the FDRE constitution with regard to the rights of women is concerned. The constitution has paved a way for women to equally enjoy land rights of women equally with men. In addition to this constitution, Oromia regional state rural land administration and use proclamation No. 130/2007 has also affirmed that women have equal rights with men to possess, use and administer rural land (Article 5(2) proc. No. 130/2007). The proclamation further provides that husband and wife have equal use right on their common land holdings and can have common holding certificate for the land that they have hold jointly (article 15(8), proc. No. 130/2007). The same article under sub article 9 dictates that if husband and wife have a private holding then they can possess separate certificate for their land holding. Here it is sound to say that both of the Oromia regional state constitution and the proclamation have sufficiently incorporated women land rights.

The research team of this study has made a deep discussion with regard to the protection of women land use right in the study area is concerned. Discussion made with woreda rural land administration and environmental protection office heads and experts deduces that in the current days women's are claiming their land rights especially at the time of divorce. But customary practices that promote male supremacy in the society are still now preventing women from claiming land rights in some places. The finding reached by FGD conducted in the study area shows that the legal awareness of women land rights in the current times is good but still now women in the remote areas are not claiming land use rights even if regional land laws has depicted gender neutral provisions on the enjoyment of land rights. The respondents believe that in the current situation, women land use rights and claim their land rights at the time of dispute is good but the legal framework with regard to women land rights is not fully implementing due to existence of derogative customary practices on the ground.

Discussion with woreda land administration office experts and woreda judges pointed that the land dispute resolution system is one of the area in which women land use rights are challenged. According to article 16 (1) (a) of proc. No. 130/2007, when dispute arises over rural landholding right, first application shall be made to kebele administration. The kebele administration then lets the dispute be resolved by negotiation and arbitration through local elders ap- 
pointed by the two parties. If the disputants are dissatisfied by the decisions of the local elders, they have the right to appeal to a regular district court. But land administration office heads and judges of sample woreda has disclosed that there is a knowledge gap by these organs. These organs also tend to favor their relatives and most of the time they fail to deliver effective and speedy justice. Women's are also facing difficulties to protect their rights through land dispute settlement mechanism. Because these organs are reluctant to resolve disputes in the best interest of the women's as they are highly influenced by local patriarchal customary practices.

\subsection{Effective Utilization of Land}

As indicated under article 6(16) of Oromia rural land administration and use proclamation No. 130/2007, any rural land user shall be deprived of his land use right under the following conditions: Leaving the land unused for two consecutive years, Leaving the holding on his own reason, or Neglect conserving the land. In order to keep holding right of land, land holder should have to cultivate the land seasonally and conserve the land effectively. This is to mean that land holder should have to take necessary care for the land under his/her possession. Among others, the law imposes an obligation on the holder to plant, conduct terracing activities and to use necessary fertilizers to keep the fertility of the land.

The discussion made with Mr. Boke Tefera, Sinana woreda land administration and environmental protection office head, some land holders are using their land in a manner that cannot keep fertility of their land. As to Tefera, due to economic problem, some land holders even doesn't use fertilizers and other mechanisms in support of protecting their land. In addition to this, some land holders doesn't plant environment friendly plantations in order to conserve their land. The FGD in study area discloses that, some land holders use their land for other purposes other than agriculture. For example some land holders use agricultural land for mineral excavations and others. Some landholders also use their agricultural land for plantation of long term trees and this is paving a way for food shortage in agrarian areas.

Generally, the research team has deduced that some landholders are not properly conserving their land and do not plant necessary plantations in support of protecting their land fertility. The holders' don't know their rights and obligations that are enshrined within the laws of the region.

\subsection{Protection of Pastoral Land Rights}

The Federal Land Administration and use Proclamation and also the Oromia regional state land administration and use proclamation do not have adequate provisions with regard to determination of pastoral land administration and use is concerned. For example these proclamations have no clear provision with regard to registration and certification of pastoral lands. The proclamations do not tell how pastoral land rights are registered and certified. The proclamations have 
not established separate dispute resolution bodies in the event of dispute in these areas. The proclamation has not given full rights for pastoralists because these areas are practically being taken for investment purposes. Unlike the agrarian/cropping areas, individuals in the pastoral areas cannot rent out/lease their land use rights.

The research team has been made discussion with these issues in the study area and reviles that pastoral land areas are neglected.. Due to this fact, pastoral areas in the study are not sufficiently registered and certified. For example our respondent Abdulatif Edris, land administration and environmental protection office head in Madda Walabu woreda one of pastoralist woreda has confirmed that there is no registration and certification in the pastoral areas. Oromia rural land administration and use proclamation is never implementing in the pastoral areas. He confirms that it is not the Oromia rural land proclamation that administers land but it the custom of the community that is administering land in these areas.

Tasfaye Sime, land administration and environmental protection office head in Dawe Qachen woreda which is pastoralist, also believes that the oromia rural land administration and use proclamation is not implementing in the pastoral areas. Land holding certificates are not being given for pastoral land holders in these areas. He also confirms that land grabbing in the name of investment is the main challenge in the pastoral areas. There are no rural land administration committees in the pastoral areas. Generally, Mr. Tesfaye believes that the current Oromia rural land administration and use proclamation is proclaimed in a manner that only suits for the agrarian community rather than pastoral areas. Generally, all of our respondents in the pastoral areas believe that pastoral lands/areas in the current time are the neglected areas in the region in general and in the study area in particular.

\section{Findings}

There are many challenges that can be noticed as a problem for the implementation of rural land laws in Oromia in general and in the study area specifically. The research team has depicted those problems and challenges faced in implementing oromia rural land laws in the following manner.

\subsection{Legislative Gaps}

The federal and regional land laws enacted prior to 2008 attempted to address tenure security only for landholders in the settled agricultural areas. Oromia regional state has considerable pastoral lands for which the regional land laws are inapplicable. The Oromia regional state has not yet issued pastoral land policy and legislation in support of these areas. An interview with all of land administration and environmental protection office heads in all of pastoral areas in the study area disclosed that, pastoral lands are administered by customary laws. There are no separate laws in response to administration of pastoral lands. This 
needs to be reconciled by amending the administration laws. There are no federal and regional laws that govern rural land registration and surveying. Regional states are also expected to issue guidelines on valuation and compensation of expropriated lands and land use, but they have yet to prepare these.

\subsection{Inadequate Institutional Capacity}

The capacity of the regional land administration agencies' in implementing the regional land administration and use laws and preparing the regional level land use plans is likewise weak. The organizational structure and levels of expertise for land administration widely differ from region to region and are inadequate in most of the regions. Improving the organizational structure and status and building the manpower capacity the regional land administration agencies in the fields of land registration, cadastral surveying, land laws, communications, land valuation and compensation for efficient service delivery will be a critical factor to the success of efforts to scale-up land administration at both the regional states level. Efforts need to be intensified in educating both landholders and land administration staff on the importance and usefulness of updating the land records as transactions occur to avoid obsolescence of the land registers.

The village land committees are working voluntarily without any remuneration, making their sustainable operation questionable. Members of these committees need training in the basics of the regional land administration and use laws to make them more effective, particularly in resolution of land disputes. The rural communities need to be educated on their land use rights and obligations through public awareness campaigns so they can exercise their rights and honor their obligations properly.

\subsection{Inadequate Financial Resources}

Weak institutional capacity is highly correlated with inadequate financial resources. The human resource and logistical capacity of the federal and regional land administration institutions can be built only if they are provided with financial resources. Lack of financial resources prevented the Oromia regional states to complete their first level land registration and certification program after it peaked in 2007 (ibid). This is also the pivotal problem in the study area. Land administration and environmental protection office heads in the study area believes that inadequate financial resources are the main problem of the sector.

\subsection{Lack of Centers of Excellence in Land Administration Education and Research}

The expansion of land administration programs requires highly qualified personnel in the fields of land registration, cadastral surveying, land law, land use planning, communication, land valuation and compensation for efficient service delivery at all levels of government. Currently, Bahir Dar University is the only institution of higher learning that has established a four year B.Sc. degree program in land administration. Attention should be given to strengthen the capac- 
ity of institutions of higher learning to train experts and engage in land administration research. Although the Federal Proclamation No. 456/2005 mandates the establishment of a system of study that focuses on identification of problems on land administration and land use to recommend solutions, no institution is engaged in focused and systematic research program on land administration and land use issues. Research on these topics is taken up by interested institutions and individuals on an ad hoc basis. It is important that major issues in land policy and its implementation are identified and given to one of the country's foremost research institutions.

\subsection{Rural Land Dispute Resolution Mechanism}

Rural land dispute resolution mechanism is also one challenge for the effective implementation of Oromia rural land laws. As it is indicated above, when dispute arises in rural land, the case is first filed to kebele administration and the kebele administrators let the parties to elect two individuals from each side. This is to mean that courts cannot here land disputes unless the dispute is filed to kebele administration firstly. But the main challenge here is that the personnel in the kebele level have no legal knowledge to entertain land disputes. Largely as stakeholders disclosed, these land dispute resolution bodies are influenced by relationships and/or payment of bribes. Decisions by the traditional elders at the local level may not always be equitable or gender sensitive. Judges and court officials within the sample woredas believe that land dispute resolution system in the region is a big challenge for the implementation of the law of the region. Discussion with Abduro Alo, Sinana woreda court president shows that dispute resolution organs at the kebele level are not acting their duties effectively because they are non trained as the same time unpaid workers. The same finding is reached by the discussion with Agerfa woreda court president and judges. Here the personnel's believe that land dispute resolution especially at the kebele level is highly challenging the implementation of land laws of the region in general and land rights of land holders specifically.

\subsection{Expropriation without Just Compensation}

Expropriation of rural land without just compensation violates Article 40(4-5) of the FDRE Constitution and Article 40 (4-5) of the Oromia Regional State Constitution, which recognize the rights of farmers and pastoralists to obtain land free of charge and protect from evictions from the lands. However, this constitutional rights have not been respected (Abdo, 2015; Ambaye, 2013). Research shows that the Government of Ethiopia evicts smallholders for stated purposes of promoting private investments including for the promotion of large-scale commercial agriculture and urbanization without adequate due process of law (ibid, Abdo 2015). Particularly, Ethiopia should protect smallholder farmers and pastoralists from forced evictions including in cases of expropriations of land for public purposes. Smallholders must be paid a just, advance and prompt compensation during an expropriation of land to translate the 
constitutional protection against evictions into practice meaningfully.

\subsection{Rural Land Valuation and Compensation Methods}

Both the FDRE constitution and Oromia regional state constitution has given lifelong use right on the rural land. But regional Governments have not enacted the land expropriation and compensation regulations in response to the protection of landholders that will be evicted from their land. Lack of standardized valuation and compensation methods and procedures are causing different valuations by different land taking agencies, resulting in different compensation values for similar lands (ibid). Stakeholders in the study area also deduce that lack of adequate compensation during expropriation is one problem for the effective implementation of land rural land laws. The amount of compensation paid for the landholders is not rehabilitating landholders whose land is expropriated.

\subsection{Existence of Double Holding Certificates within the Same Pilot}

Double holding certificate is also one of the pivotal problems for the effective implementation of rural land laws and land rights of landholders in the study area. Respondents for this study have indicated the existence of double landholding certificates within the same pilot of land. The respondents have confirmed that landholders are selling their land and both the seller and the buyer have their own landholding certificate and this is creating a big challenge at the time of dispute. The buyer and/or the person who take the land on rental bases lobby the concerned stakeholders in order to get landholding certificates. Even they give have been bribes in order to get the holding certificate. Discussion within the study area court presidents and judges of Bale zone have disclosed that the existence of double landholding certificates with in the same pilot is also highly challenging the speedy trial process of the courts.

\subsection{Land Grabbing}

In general, the practice of the large-scale land transfer in Oromia and other regional States of Ethiopia has been criticized for at least five reasons. First, it leads to the displacement of local communities from their lands without just, advance and prompt compensation, which in turn undermines their livelihoods and food security (Grant, 2015; Tura, 2017). Second, the government promotes large-scale agricultural investments to produce crops for the export market despite the critical food shortages in the country (Rahmato, 2011). Third, the large-scale agricultural investment policy is implemented in a manner excluding local populations and harming the environment (Grant, 2015; Dessalegn, 2011). Fourth, the federal government has leased out the land to private entities by usurping the constitutional power of regional States regarding land and other natural resources administration that is stipulated under Article 52(2) (d) of the FDRE Constitution (Zewdie, 2013). Fifth, most investors have failed to implement their projects for which they take lands in accordance with terms agreed in land lease 
contracts (Abdo, 2015). For instance, only $46 \%$ of the land has been utilized as agreed between the Government and private investors in the Regional State of Oromia (Addis-Fortune, 2017).

In the mean time, land grabbing especially in the name of investment and city expansion is the main problem. The practice of the large-scale land transfer in Oromia leads to the displacement of local communities from their lands without just, advance and prompt compensation, which in turn undermines their livelihoods and food security (Grant, 2015; Hindeya, 2017, Lavers, 2012a; Tura, 2017). In addition to this, large-scale agricultural investment policy is implemented in a manner excluding local populations and harming the environment (Grant, 2015; Dessalegn, 2011, Lavers, 2012a). Discussion with respondents in the study area also discloses that land grabbing in some areas of study zone highly displacing land holders without just compensation. It is also harming the environment because the investors are not conserving the land granted for the investment purpose. Investors are not planting in the area that they took for the investment purposes. In addition to these, respondents are also confirms that land grabbing in the name of investment is also perpetuating grievances within the society.

\subsection{Disguised Land Sale}

Both theFDRE constitution and the Oromia regional state constitution prohibits sale of land. The FDRE constitution under article 40(3) of it has confirmed that 'The right to ownership of rural and urban land, as well as of all natural resources, is exclusively vested in the State and in the peoples of Ethiopia. Land is a common property of the Nations, Nationalities and Peoples of Ethiopia and shall not be subject to sale or to other means of exchange. The same message is depicted under article 40(3) of the revised Oromia regional state constitution. But these constitutional provisions are not implementing on the ground in the study area. Discussion made with the respondents of this study has disclosed that land holders are selling their land like any other assets. Land holders' sale their land by entering a fake contract of donation between the buyer and the seller. A discussion made with Bale zone high court judges shows land disputes are highly increasing in the court. Most of these land disputes are related with disguised land sale disputes.

\subsection{Lack of Awareness on the Land Laws of the Region}

In addition to the above listed factors, lack of awareness of the land laws of the region is also one of the pivotal problems for the effective implementation of the land laws of the region in the study area. The Oromia regional rural land administration and use proclamation has depicted provisions on the rights and obligation of land holders separately. But this study has found that, landholders have no clue on those rights and obligations depicted on it. Because of this, landholders do not claim their rights and also they do not abide by the obligations specified within the proclamation. 


\section{Conclusions}

In July 2005, the Federal government has enacted the federal rural land administration and use proclamation No. 456/2005. This proclamation bestows the regional governments the power to enact their respective regional rural land administration and use laws and establish institutions to each regional state council so as to implement Federal Rural Land Administration and Use Proc. No. $456 / 2005$ in the regions. Because of the stipulation of the federal frame work proclamation No. 456/05, the Oromia regional state has enacted the current rural land administration and use law which is termed as Oromia rural land administration and use proclamation No. 130/2007. Proclamation No. 130/2007 has incorporated major rights of landholders under Article 6(1) of it. One of the rights that Oromia rural land proclamation provided for the landholders is the right to rent out up to half of his/her total holding for three years if modern farming technology is utilized.

Nevertheless, agreements to rent rural holdings won't be valid unless approved and registered by the Bureau. Furthermore, the law requires that all family members including women, those who have interests in the land, must give their consent before any agreement to rent out rural land holding is concluded. But the practice of the study area shows that land holders are not entering valid contract with the lessee. Even they enter a contract for more than three years and they won't register the contract of rent by the relevant organ.

Both the revised constitution of Oromia and proclamation No. 130/2007 mandates any individual or organ whose land holding is taken for public uses to have the right to get compensation for his properties and benefits get proportional replacement for his holding. Most of our study populations are unhappy by the amount of compensation paid at the time of expropriation. They believe that the amount of compensation paid in lieu of expropriation of rural land is not rehabilitating the victims to their previous position.

The proclamation has also affirmed that women have equal rights with men to possess, use and administer rural land. The proclamation further provides that husband and wife have equal use right on their common land holdings and can have common holding certificate for the land that they have hold jointly. But this study has found that customary practices that promote male supremacy in the society are still now preventing women from claiming land rights in some places.

FDRE and revised Oromia regional state constitutions and both of the Federal and Oromia land administration and use proclamation are incorporate pastoral land rights. But this study has framed that both of the federal and Oromia regional state land laws do not have adequate provisions with regard to determination of pastoral land administration and use is concerned. For example, these proclamations have no clear provision with regard to registration and certification of pastoral lands. The proclamations do not tell how pastoral land rights are registered and certified, by whose name and etc. are not indicated 
within the proclamations.

The proclamations have not established separate dispute resolution bodies in the event of dispute in these areas. The proclamation has not given full rights for pastoralists because these areas are practically being taken for investment purposes. Unlike the agrarian/cropping areas, individuals in the pastoral areas cannot rent out/lease their land use rights. Oromia land administration and use proclamation and its implementing regulation have no fully fledged provisions in support of these areas. Due to this fact, pastoral areas in the study are not sufficiently registered and certified.

There are certain obligations imposed on the use right holder. Some of the obligations imposed by law on the user include: obligation to proper management of rural land, obligation to proper management of farm land, obligation to proper management of grazing land and obligation to proper utilization of lands. For instance, the proclamation under Article 6(16) provides for the main obligations that must be fulfilled by all rural land users to continue exercising use rights over their holdings. In the first place, any rural land user who fails to conserve his holdings may lose his/her holding rights. Secondly, any rural land user who leaves his holdings uncultivated or unused for two consecutive years would be deprived of his/her use rights.

The Proclamation contains provisions that provide for proper management and conservation of the land by abstaining from activities that exacerbate soil erosion, forest clearing and plotting sloppy land and refraining from planting tree species that may cause damage to the land and eradicate weeds that cause harm to land. So in order to keep holding right of land, land holder should have to cultivate the land seasonally and conserve the land effectively. This is to mean that land holder should have to take necessary care for the land under his/her possession. Among others, this law imposes an obligation on the holder to plant necessary plantations, conduct terracing activities and to use necessary fertilizers to keep the fertility of the land. But the discussion made on shows opposite answer on the utilization of rural land is concerned in the study area. Respondents of this study have confirmed that, some land holders are using their land in a manner that cannot keep fertility of their land.

Generally, the research team has deduced that some landholders are not properly conserving their land and do not plant necessary plantations in support of protecting their land fertility. The holders' don't know their rights and obligations that are enshrined within the laws of the region. Finally, the study has framed main challenges for the effective implementation of rural land laws on the ground. Among others, legislative gaps, inadequate institutional capacity, inadequate financial resources, lack of centers of excellence in land administration education and research, rural land dispute resolution mechanism, rural land valuation and compensation methods, existence of double holding certificates within the same pilot, Land grabbing and disguised land sale are framed as a basic challenge for the implementation of the land laws in Oromia in general and in the study area specifically. 


\section{Recommendations}

This study has found that the current land law of the region is enacted in a manner that suits only for agrarian/highland areas but not for lowland/pastoralist areas. Pastoralist lands are practically neglected areas in the region in general and in the study area specifically. So, in order to alleviate this problem, it is imperative for the region to enact separate land laws for pastoralist land areas by clearly indicating how pastoralist lands are used, registered and certified, compensated at the time of expropriation and how disputes are resolved in these areas.

The regional government should have to enact other specific guidelines in support of the regions land law. For example, it is vital for the regions government to enact specific laws shows how compensation during expropriation is calculated for every property situated on the land.

The Oromia rural land proclamation has mandated kebele administrators and elders to entertain land disputes before the dispute is going to the regular court but this study has found that these organs are not conducting their function well and they are not submitting their finding to the court of laws at the possible time. This is creating unnecessary cumbersome for the party to get speedy justice. So it is imperative for the regions land law to indicate the obligations of these bodies shall be clear. Moreover, the law should have to establish mechanism for the dissatisfied party to lodge his/her case directly to the court if elders and kebele administrators are unable to give feedback within the time specified under the law.

The study has also found that the kebele administrators, elders and land administration committees are reluctant to handle cases because they are not trained and non-paid personnel within the land administration institutions. So in order to boost their confidence, it is essential for the law to make adjustments including supporting these organs with adequately trained and full time paid judges or other experts and making arrangements to train them on the substantive contents of law and the fundamental ethical values. It is also imperative to establish an incentive mechanism for these bodies in order to effectively handle their communities' problems.

The land administration and use office of the woreda is understaffed and there are no adequate human powers. The office is occupied only with certain experts like agriculture and geography experts. So there is a need to arrange the office with adequate human power including lawyers, GIS experts, economists and other relevant experts.

The study has also found that the land administration office/sector is also underfinanced sector Therefore the office shall be equipped with sufficient finance and logistics. Develop mechanisms of training experts of the subject area and different stakeholders including judges, kebele land administration committees and kebele administrators in order to equip their overall understanding of the land laws of the region. Arrange regular round table discussions for the 
land administration staffs, the judiciary, kebele land administration committees and kebele administrators in order to avoid the overlap of functions between all these institutions.

\section{Conflicts of Interest}

The authors declare no conflicts of interest regarding the publication of this paper.

\section{References}

(2012). Voluntary Guidelines on the Responsible Governance of Tenure of Land, Fisheries and Forests in the Context of National Food Security.

Abdo, M. (2015). Reforming Ethiopia's Expropriation Law. Mizan Law Review, 9, 301-340. https://doi.org/10.4314/mlr.v9i2.3

Addis-Fortune (2017). Oromia Land Mang't to Welcome Investors Next Month 6. https://addisfortune.net/articles/oromialand

Ambaye, D. W. (2013). Land Rights and Expropriation in Ethiopia. Berlin: Springer.

Deninger, K. et al. (2008). Rural Land Certification in Ethiopia: Process, Initial Impact, and Implication for Other African Country. World Development, 36, 1786-1812. https://doi.org/10.1016/j.worlddev.2007.09.012

Dessalegn, R. (2011). Land to Investors: Large-Scale Land Transfers in Ethiopia. Addis Ababa: Forum for Social Studies.

Federal Democratic Republic of Ethiopia Constitution (1995). Proclamation No. 1/1995, Negarit Gazeta, Year 1, No. 1.

Federal Rural Land Administration and Use Proclamation (2005). Proc. No. 456/2005, NegaritGazeta, Year 11, No. 44.

Grant et al. (2015). Land Grabbing, Sustainable Development and Human Rights. Transnational Environmental Law, 4, 289-317. https://doi.org/10.1017/S2047102515000023

Ling, D. C., \& Wayne, A. R. (2005). Real Estate Principles: A Value Approach. New York: McGraw Hill Irwin.

Oromia Rural Land Administration and Use Proclamation (2007). Proclamation No. 130/2007, Proclamation to Amend Proc. No. 56/2002, 70/2003, and 103/2005, Megeleta Oromia, 15th Year, No. 12.

Oromia Rural Land Use and Administration (2003). Proclamation No. 70/2003, Proclamation to Amend Proclamation 56/2002, Megaleta Oromia, 9th Year, No. 12.

Oromia Rural Land Use and Administration (2005). Proclamation No. 103/2005, Proclamation to Amend Proclamation No. 56/2002.

Oromia Rural Land Use and Administration Proclamation (2002). Proclamation No. 56/2002, Magaleta Orormia, 9th Year, No. 2.

Palmer, D. et al. (2009). Towards Improved Land Governance. Rome: Food and Agriculture Organization of the United Nations United Nations Human Settlements Programme.

Seifu, G. (2010). Rural Land Tenure Security in the Oromia National Regional State. Ethiopian Business Law Series Vol. 3.

Sen, A. (1981). Poverty and Famines: An Essay on Entitlement and Deprivation.

Shipton, P. (2009). Mortgaging the Ancestors: Ideologies of Attachment in Africa. New 
Haven and London: Yale University Press.

https://doi.org/10.12987/yale/9780300116021.001.0001

Tigistu, G. (2011). Experience and Future Direction in Ethiopian Rural Land Administration. In Annual World Bank Conference on Land and Poverty (pp. 19-20). Washington, DC, USA.

Tura, H. A. (2017). Linking Land Rights and the Right to Adequate Food in Ethiopia: Normative and Implementation Gaps. Nordic Journal of Human Rights, 35, 85-105. https://doi.org/10.1080/18918131.2017.1312860

USAID (2012). Dispute Resolution in Four Regional States of Ethiopia. A Consultancy Report, Addis Ababa: Ministry of Agriculture. 